\title{
Fish Feeder for Aquaculture with Fish Feed Remaining and Feed Out Monitoring System Based on IoT
}

\section{Alat Bantu Pemberi Pakan Ikan Budidaya dengan Sistem Monitoring Sisa Pakan dan Pakan Keluar Berbasis IoT}

\author{
Ali Rizal Chaidir ${ }^{1}$, Gamma Aditya Rahardi ${ }^{2}$, Haidzar Nurdiansyah ${ }^{3}$ \\ \{ali.rizal@unej.ac.id ${ }^{1}$, gamma.rahardi@unej.ac.id ${ }^{2}$, haidzar.teknik@unej.ac.id ${ }^{3}$ \}
}

Fakultas Teknik, Universitas Jember, Jalan Kalimantan No. 37, Kampus Tegal Boto, Jember, Indonesia 68121

\begin{abstract}
Feeding fish is a process that affects fish yields. Undisciplined feeding of fish resulted in decreased quality and quantity of fish. The potential for this problem can be reduced by implementing an IoT-based technology. That technology needs to have a monitoring system for remaining feed and the success of feeding. This study using a proximity sensor and infrared distance sensor for the monitoring system for the fish feeder. The results obtained are that the infrared distance sensor can provide information about the remaining fish feed more accurately after being calibrated, the average percentage error of the total test is 5,1\%. While the proximity infrared sensor can provide information on the success of throwing feed, from the total testing of the proximity sensor, the success rate of detecting throw feed is $100 \%$. Both information can be monitored via the Blynk platform on the user's smartphone.
\end{abstract}

Keywords - Fish Feeder; IoT; Monitoring System.

\begin{abstract}
Abstrak. Proses pemberikan pakan ikan merupakan salah satu proses yang memberikan pengaruh yang besar terhadap hasil panan. Pemberian pakan ikan yang tidak disiplin mengakibatkan menurunnya kualitas dan kuantitas ikan. Potensi terjadinya masalah tersbut dapat dikurangi dengan menerapkan sebuah teknologi berbasisi IoT. Teknologi tersebut perlu memiliki sistem monitoring sisa pakan dan keberhasilan lontaran pakan. Pada penelitian ini menggunakan sensor proximity dan sensor jarak infrared untuk sistem monitoring alat pemberian pakan ikan. Hasil yang diperoleh adalah sensor jarak infrared dapat memberikan informasi tentang sisa pakan ikan lebih akurat setelah dikalibrasi, rata-rata persentase kesalahan dari total pengujian adalah sebesar $5,1 \%$. Sedangkan sensor proximity infrared dapat memberikan informasi keberhasilan lontaran pakan, dari total pengujian sensor proximity, tingkat keberhasilan mendeteksi lontaran pakan sebesar 100\%. Kedua informasi tersebut dapat dipantau melalui platform Blynk di ponsel cerdas pengguna.
\end{abstract}

Kata Kunci - IoT; Pemberi Pakan Ikan; Sistem Pemantauan

\section{Pendahuluan}

Budidaya ikan adalah salah satu kegiatan peternakan yang cukup banyak dilakukan masyarakat di Indonesia. Menurut Badan Pusat Statistik, pada tahun 2018 terdapat 258 perusahan budidaya ikan di seluruh Indonesia, jumlah perusahan tersebut dibagi ke dalam jenis budidaya ikan air tawar, tambak, pembenihan, dan laut. Selain perusahaan skala besar tersebut, terdapat juga pembudidaya-pembudidaya ikan rumahan, dan tentu jumlahnya cukup banyak.

Dalam proses budidaya ikan terdapat faktor-faktor yang mempengaruhi kuantitas dan kualitas hasil panen. Diantara faktor-faktor tersebut adalah pemberian pakan ikan. Pemberian pakan ikan yang kurang akan mengakibatkan pertumbuhan ikan kekurangan gizi, sedangkan pemberian ikan yang terlalu banyak akan mengakibatkan kolam ikan menjadi kotor dan makanan akan terbuang, dan jika pemberian pakan ikan tidak dilakukan dengan disiplin maka akan memungkinkan tingkat kematian ikan menjadi tinggi.

Penerapan teknologi merupakan salah satu cara untuk membantu manusia dalam mempercepat terselesainya suatu pekerjaan, dan juga membantu manusia mengurangi potensi kegagalan dari suatu proses pekerjaan. Sebagaimana yang telah diketahui perkembangan teknologi informasi sangat berkembang dengan cepat, seperti misalnya di bidang otomasi dan IoT.

Cukup banyak penelitian yang telah menerapkan teknologi IoT atau pengendalian dan monitoring secara nirkabel dalam bidang akuakultur, diantaranya adalah untuk proses pemberikan pakan ikan. Beberapa penelitian memanfaatkan motor servo pada sistem buka tutup tempat keluarnya pakan ikan [1] [2] [3] [4], dan menggunakan motor brushless sebagai komponen utama pelontar pakan [5]. Dari penelitian-penelitian tersebut masih belum terlihat terdapat sistem pemantauan yang menunjukan sisa persentase pakan ikan dalam wadah dan sistem pemantauan keberhasilan pakan keluar dari alat.

Pada penelitian ini menghasilkan suatu produk teknologi otomasi yang berbasis IoT. Teknologi ini digunakan untuk membantu pembudidaya ikan dalam melakukan proses pemberi pakan ikan serta dapat melakukan penjadwalan pemberikan pakan, pemantauan sisa pakan dalam wadah dan pemantauan keberhasilan pakan keluar, sehingga diharapkan dapat mengurangi potensi kekurangan gizi dan tingkat kematian ikan. 


\section{A. Sensor infrared}

Sensor infrared memiliki beberapa fungsi, diantaranya sebagai detektor dan proteksi. Contoh penggunaan infrared adalah sebagai deteksi objek yang ada di depannya. Terdapat beberapa bentuk sensor infrared, seperti yang ditunjukkan pada Gambar 1 dan 2. Gambar 1 adalah sebuah infrared DMS Sensor DMS-80, memiliki kemampuan jarak pengukuran mulai 10-80 cm, dan tidak dipengaruhi oleh warna objek pantulan, output dari sensor tersebut adalah tegangan analog, perubahan tegangan dipengaruhi oleh jarak sensor dengan objek, sehingga cocok digunakan untuk mengukur jarak. Gambar 2 adalah infrared proximity sensor distance switch adjustable, sensor ini memiliki output digital dan jarak pengukuran dapat diatur sesuai keinginan, sensor ini lebih cocok digunakan untuk mendeteksi objek di depannya dengan jarak tertentu yang dapat diatur.

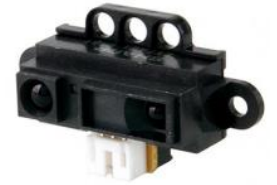

Gambar 1. Infrared DMS Sensor DMS80 (https://digiwarestore.com/)

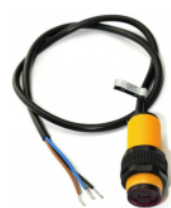

Gambar 2. Infrared Proximity Sensor (https://digiwarestore.com/)

\section{B. Internet of things}

IoT (Internet if Things) adalah sistem perangkat komputasi yang saling berhubungan, dilengkapi dengan pengidentifikasi unit dari kemampuan untuk melakukan transfer data melalui jaringan internet [6]. Terdapat empat elemen penting dalam sistem IoT, yaitu:

1. Sensor

2. Pengidentifikasi data

3. Software

4. Koneksi internet

Ide utama dari IoT adalah menghubungkan benda apapun seperti sensor, mesin, orang, hewan, tanaman dan modul prosesor melalui koneksi internet untuk pemantauan maupun pengendalian. Penerapan sistem IoT cukup luas, diantaranya adalah untuk pemantauan kinerja dari mobil listrik [7], robotik [8], pertanian [9], dan kesehatan [10].

Fungsi pemantauan membutuhkan setidaknya sensor dan fungsi pengendalian suatu gerakan setidaknya membutuhkan aktuator. Gambar 3 menunjukkan alur kerja dari sistem IoT, pada gambar tersebut data di suatu lingkungan diakuisisi menggunakan bantuan sebuah sensor, data tersebut diproses di dalam mikrokontroler dan selanjutnya dikirimkan melalui jaringan internet dengan bantuan modul WiFi ke sebuah perangkat lainnya, jadi arah kerjanya dari bawah ke atas, berbeda jika digunakan untuk melakukan pengendalian untuk aktuator, maka alur kerjanya dari atas ke bawah, mikrokontroler digunakan untuk mengendalikan aktuator, dan blok sensing element pada gambar tersebut adalah digantikan dengan sebuah aktuator.

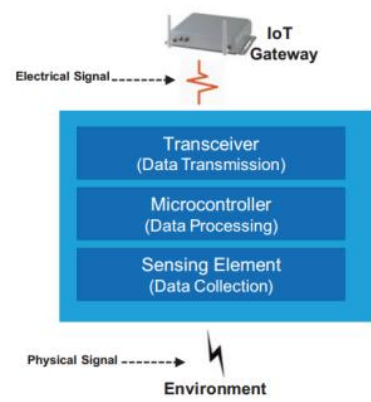

\section{Board esp32-wroom}

Gambar 3. Alur Kerja dari Sistem IoT

Board ESP32-WROOM adalah sebuah papan rangkaian elektronik yang dapat digunakan dalam sistem IoT. ESP32-WROOM memiliki modul Wi-Fi dan BT yang dimanfaatkan untuk berbagai aplikasi, contohnya adalah untuk jaringan sensor, hal tersebut dikarenakan papan ESP32-WROOM memiliki beberapa fasilitas, diantaranya adalah komunikasi SPI, IIC, UART, I/O Digital, PWM, dan beberapa fasilitas yang lain. Gambar 4 menunjukkan bentuk fisik dan pinout dari ESP32-WROOM. 


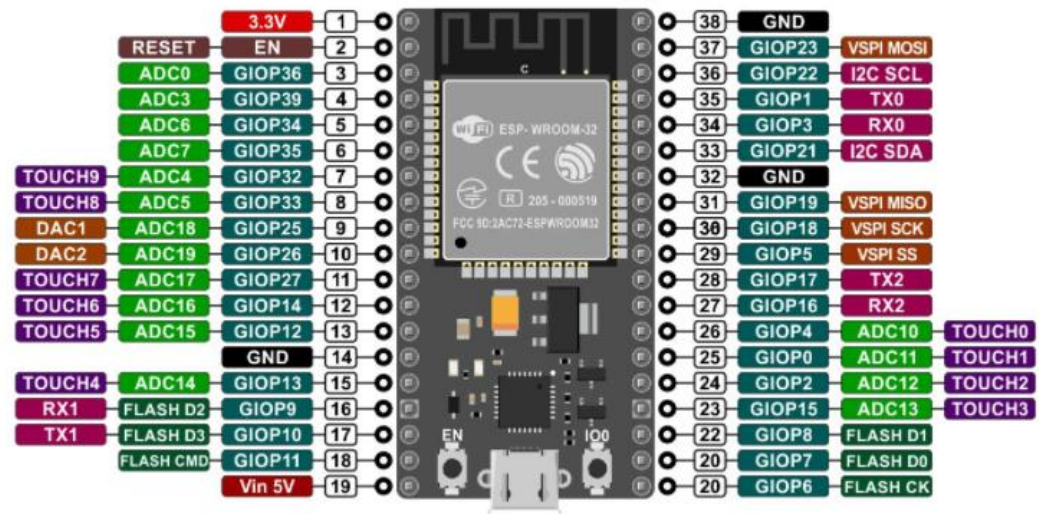

Gambar 4. Pinout ESP32-WROOM

(https://embeddednesia.com/)

\section{Platform Blynk}

Blynk adalah sebuah platform IoT yang dapat diinstall di smartphone dan digunakan untuk sistem antarmuka, mendukung lebih dari 400 papan elektronik seperti papan elektronik Arduino, MicroPython, dan lain-lain. Blynk dirancang untuk sistem IoT, dapat mengendalikan perangkat keras dari jarak jauh, menampilkan data hasil pembacaan sensor, dan melihatnya secara visual serta dapat menyimpan data. Terdapat tiga komponen utama dalam platform ini, yaitu:

1. Blynk App - memungkinkan pengguna memnuat antarmuka untuk proyek yang dibuat, terdapat widget yang cukup beragam yang dapat digunakan

2. Blynk Server - bertugas untuk mengkomunikasikan smartphone dengan perangkat keras. Pengguna dapat menjalankan server ini secara lokal.

3. Blynk Libraries - digunakan untuk mempemudah dalam pembuatan code program, misalnya di Arduino.

Ilustrasi dari alur kerja Blynk dapat dilihat pada Gambar 5

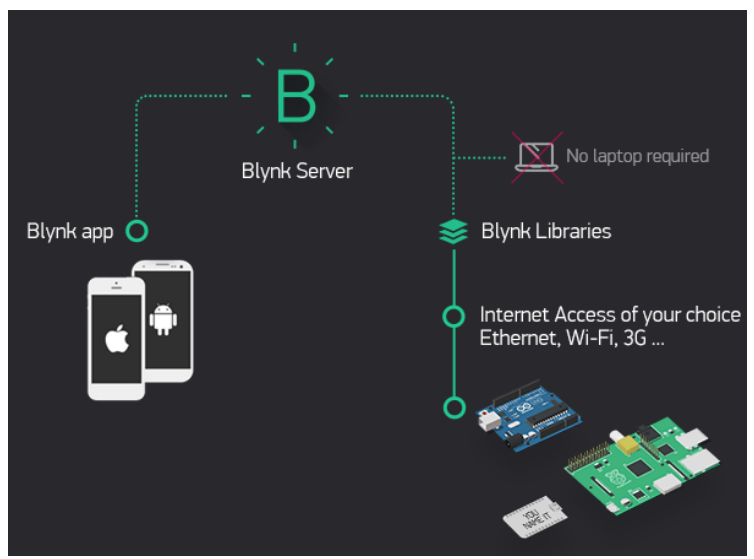

Gambar 5. Ilustrasi Alur Kerja dari Blynk (https://blynk.io/)

\section{METODE}

Terdapat tiga bagian yang dibuat pada sistem ini. Tiga bagian itu adalah rangkaian elektronik, sistem mekanik, dan algoritma program. Rangkaian elektronink yang digunakan ditunjukkan pada Gambar 6, terlihat bahwa rangkaian yang digunakan terdiri dari komponen utamanya adalah ESP32 sebagai pemroses data hasil pembacaan sensor, dan mengirimkan data ke aktuator. Terdapat dua sensor yang digunakan pada sistem ini, sensor proximity digunakan untuk mendeteksi keberhasilan pakan terlontar, dan sensor jarak infrared digunakan untuk memantau sisa pakan di wadah. 
Selain sensor terdapat aktuator, aktuator yang digunakan terdiri dari motor DC 1000 RPM sebagai pelontar dan motor servo sebagai pembuka katup wadah pakan.

Rangkaian elektronik tidak dapat berdiri sendiri untuk mengerjakan tugas dari sistem ini, diperlukan algoritma program dan sistem mekanik. Sistem mekanik yang digunakan ditunjukkan pada Gambar 7, terdiri dari wadah pakan

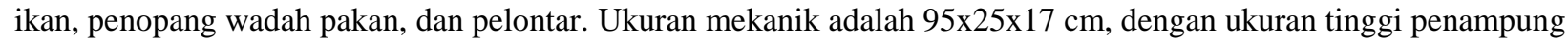
pakan adalah $35 \mathrm{~cm}$ dengan diameter $25 \mathrm{~cm}$, dan tinggi penopang penampung pakan $60 \mathrm{~cm}$ dengan lebar $17 \mathrm{~cm}$ serta panjang $25 \mathrm{~cm}$. sedangkan untuk ukuran kotak pelontar adalah 12x4,5x9 cm. Sedangkan untuk Algoritma yang digunakan adalah sebagai berikut:

1. Menyiapkan library untuk komunikasi IoT menggunakan Blynk.

2. Menyiapkan library untuk motor servo

3. Menyiapkan pin I/O digital yang digunakan

4. Menghubungkan papan elektronik ESP32 dengan jaringan internet

5. Membaca dan melakukan kalibrasi nilai output dari sensor jarak infrared

6. Jika mode pengoperasian yang dipilih adalah manual lakukan langkah ke 7, dan jika otomatis lakukan mulai langkah ke 11

7. Jika tombol pelontar "on" ditekan maka motor DC akan berputar, jika tombol "off" ditekan maka motor DC berhenti berputar

8. Sensor proximity infrared membaca lontaran pakan ikan, dan mengirimkan informasi ke paltform Blynk

9. Sensor jarak infrared membaca informasi sisa pakan dalam wadah, dan mengirimkan informasi ke platform Blynk 10. Kembali ke langkah 6

11. Lakukan lontaran pakan sesuai dengan jadwal lontaran yang telah diatur, hentikan putaran motor setelah selesai 12. Lakukan kembali mulai langkah 8

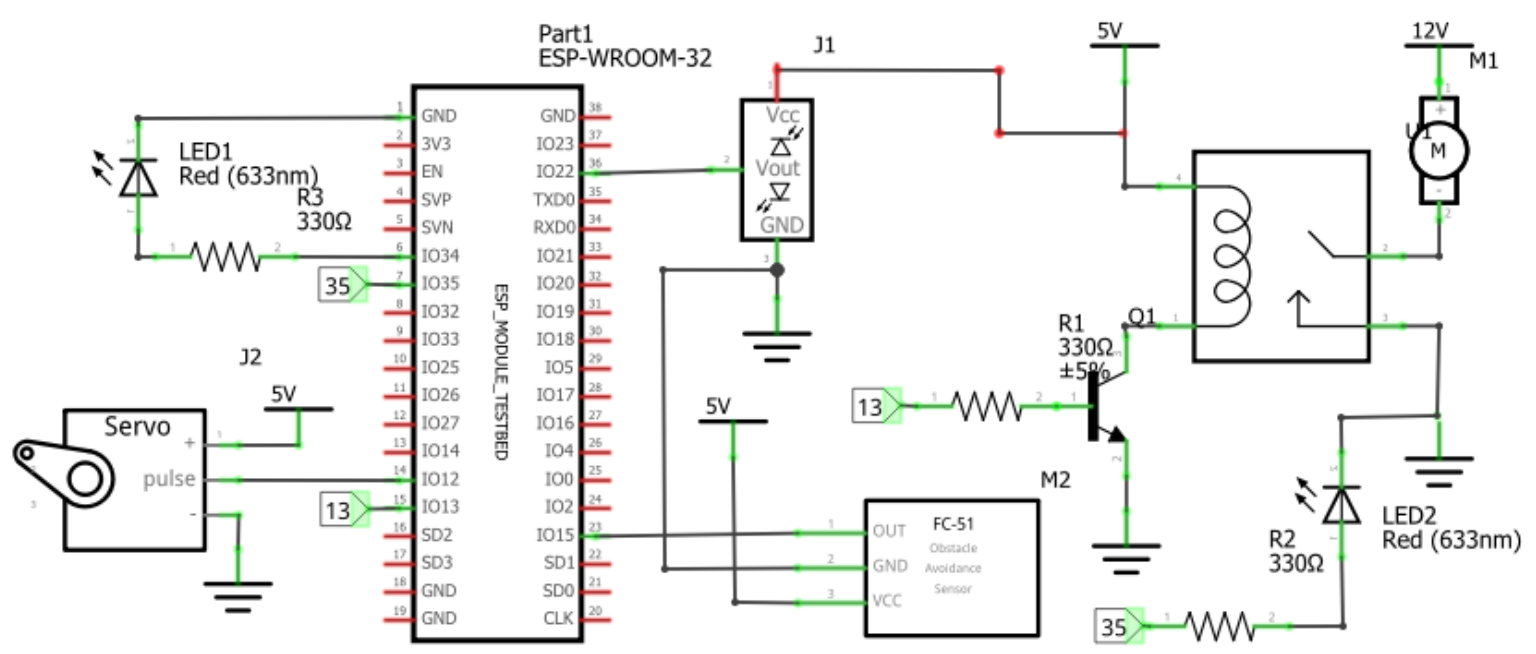

Gambar 6. Gambar Rangkaian Elektronik 


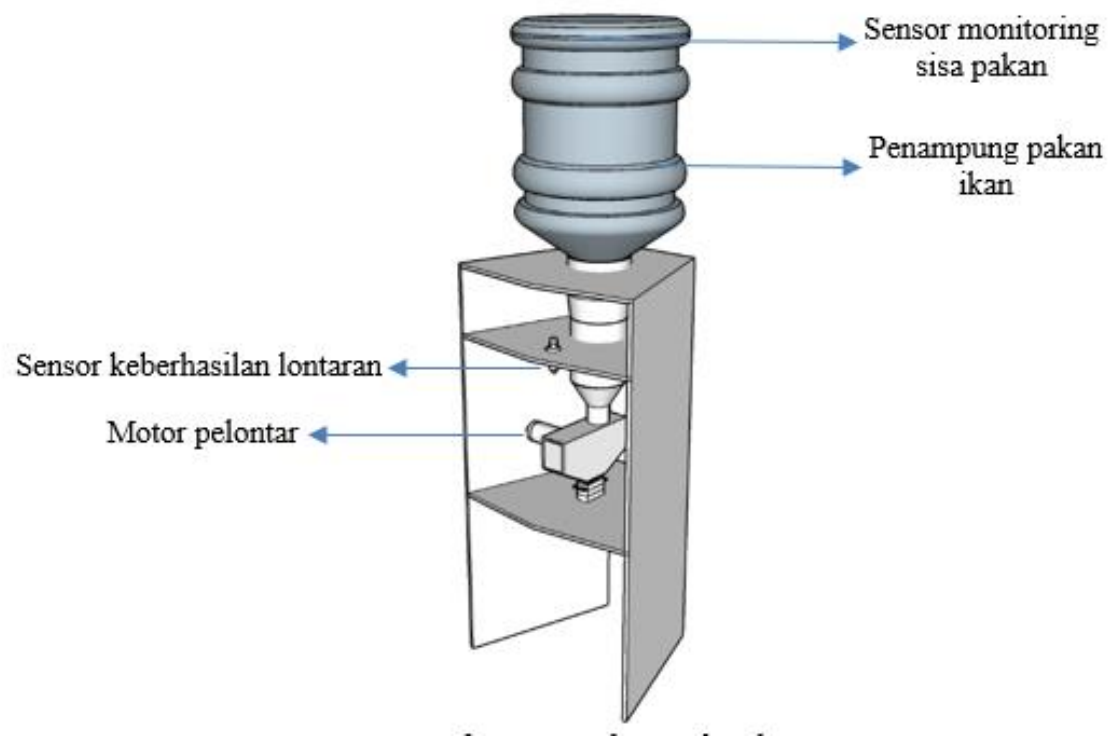

Gambar 7. Gambar Mekanik

\section{Hasil dan Pembahasan}

Alat yang dibuat telah memiliki pelontar pakan sesuai jadwal yang diberikan oleh pengguna dan secara manual, pemantauan sisa pakan, dan pemantauan pakan terlontar. Fungsi tersebut dipantau dan dilakukan melalui sebuah gawai. Jarak lontaran adalah kurang lebih sejauh 1 meter. Gambar 8 menunjukkan tampilan antarmuka di gawai dan Gambar 9 adalah bentuk dari alat pelontar pakan ikan. Pengguna dapat memilih mode pemberikan pakan ikan melalui gawai, apakah harus manual atau sesuai dengan jadwal pemberian pakan. Di tampilan tersebut juga terdapat informasi mengenai sisa pakan yang ada di wadah pakan, dan juga indikator tentang keberhasilan pakan terlontar, yaitu melalui indikator proximity.

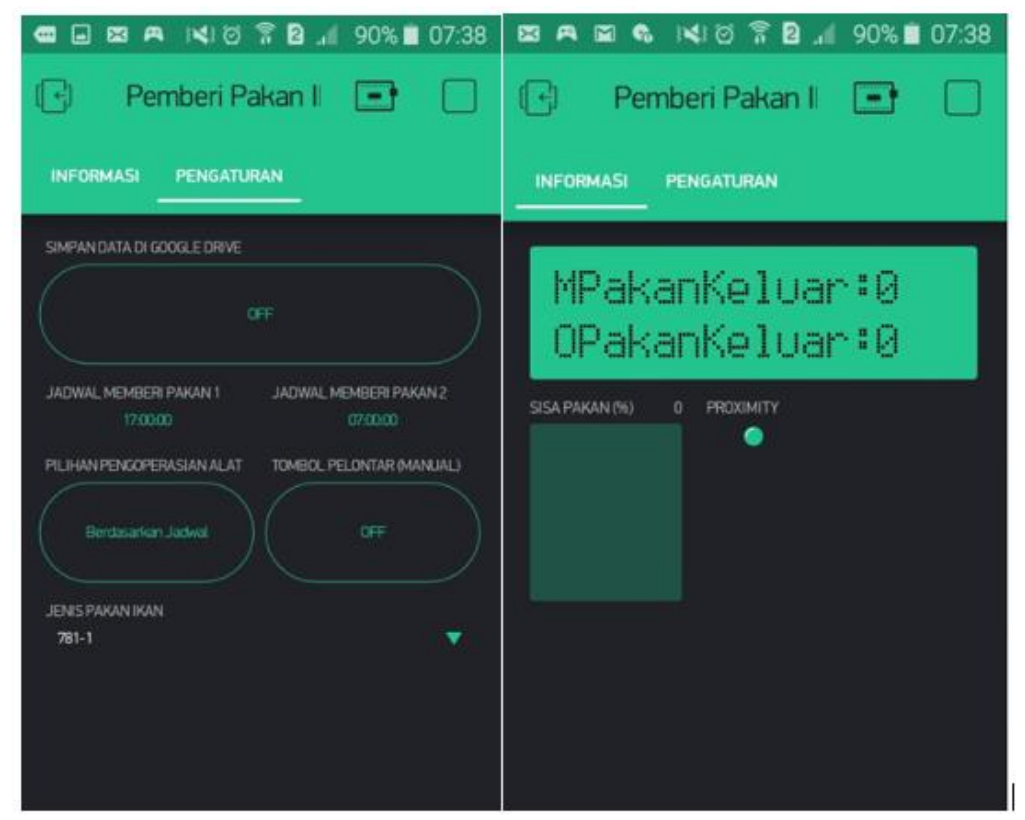

Gambar 8. Tampilan Antarmuka pada Gawai Pengguna 


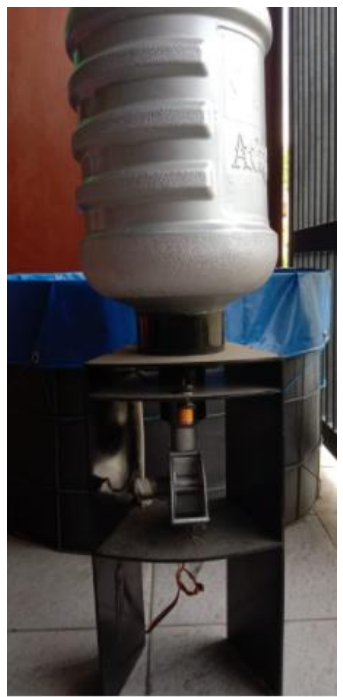

Gambar 9. Bentuk Alat

Beberapa pengujian dilakukan untuk mengetahui spesifikasi dari alat yang telah dibuat. Pengujian tersebut diantaranya adalah jumlah pakan (gr) yang terlontar berdasarkan lama waktu lontaran (detik), konsistensi waktu yang dibutuhkan untuk melontar semua pakan, dan tingkat kegagalan sistem selama alat bekerja. Pengujian dilakukan menggunakan jenis pakan ikan jenis PF1000.

\section{A. Pengujian berat pakan terlontar berdasarkan waktu}

Tabel 1 menunjukkan hasil pengujian alat untuk memberikan informasi mengenai seberapa banyak pakan terlontar bedasarkan lama waktu lontaran. Jika dilihat dari tabel tersebut maka akan diperoleh informasi bahwa setiap 5 detik rata-rata pakan yang terlontar adalah sebanyak 89,6 Gram dan setiap 10 detik adalah sebanyak 180,3 gram.

Tabel 1. Pengujian Waktu Lontaran Selama 5 Detik

\begin{tabular}{ll}
\hline Waktu (detik) & Berat (gram) \\
\hline 5 & 86 \\
\hline 5 & 89 \\
\hline 5 & 98 \\
\hline 5 & 94 \\
\hline 5 & 88 \\
\hline 10 & 178 \\
\hline 10 & 178 \\
\hline 10 & 184 \\
\hline 10 & 186 \\
\hline
\end{tabular}

\section{B. Pengujian tingkat keakurasian pembacaan sisa pakan}

Berikutnya adalah melakuan pengujian untuk mendapatkan informasi tentang hubungan antara hasil pembacaan sensor sharp (sensor jarak) dengan persentase sisa pakan ikan yang ada di penampungan. Langkah awal yang dilakukan adalah mendapatkan nilai dari hasil pembacaan sensor ketika keadaan penampungan pakan kosong dan tersisi penuh, nilai ADC yang diperoleh adalah sebesar 750 untuk keadaan kosong dan 4095 untuk keadaan penuh, rentan nilai tersebut kemudian dikonversi menjadi 0 untuk kosong dan 3345 untuk terisi penuh, kemudian nilai hasil konversi tersebut kemudian dikonversi lagi dalam bentuk persentase. Tabel 2 menunjukkan hasil dari konversi dan digunaan untuk dasar mengkalibrasi agar hasil persentase sesuai dengan keadaan sisa pakan di penampungan. Hasil pengujian pada Tabel 3 akan menghasilkan sebuah persamaan yang nantinya digunakan untuk memperbaiki hasil pengukuran (Gambar 10). Tabel 3 menunjukkan hasil kalibrasi dari penggunaan sensor. 
Procedia of Engineering and Life Science Vol. 1. No. 2 Juni 2021

Seminar Nasional \& Call Paper Fakultas Sains dan Teknologi (SENASAINS 2nd)

Universitas Muhammadiyah Sidoarjo

Tabel 2. Hasil Pengujian untuk Informasi Sisa Pakan Ikan

\begin{tabular}{cccc}
\hline Sisa pakan (\%) & Gram & Sensor (\%) & Error (\%) \\
\hline 10 & 770,5 & 2 & 80 \\
\hline 20 & 1541 & 5 & 75 \\
\hline 30 & 2311,5 & 7 & 76,7 \\
\hline 40 & 3082 & 11 & 72 \\
\hline 50 & 3852,5 & 17 & 66 \\
\hline 60 & 4623 & 21 & 65 \\
\hline 70 & 5393,5 & 31 & 55,7 \\
\hline 80 & 6164 & 45 & 43 \\
\hline 90 & 6934,5 & 73 & 3 \\
\hline 100 & 7705 & 97 &
\end{tabular}

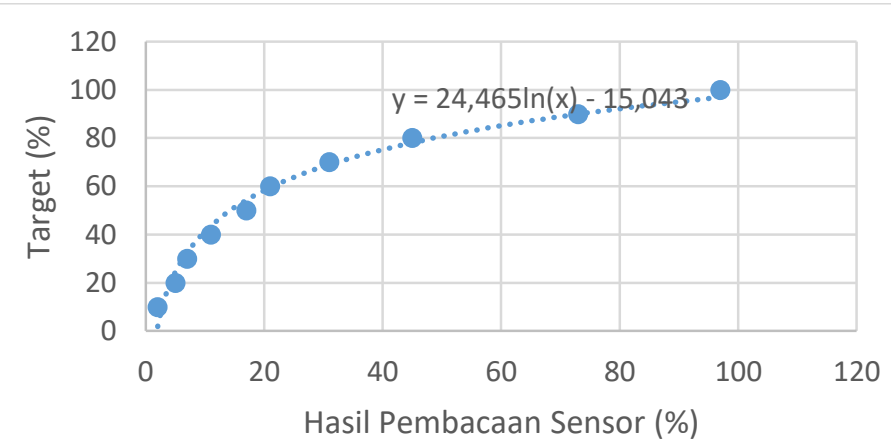

Gambar 10. Hubungan antara hasil pembacaan sensor dan target

Tabel 3. Hasil Pengujian Hasil Kalibrasi

\begin{tabular}{llll}
\hline Sisa pakan (\%) & Gram & Sensor (\%) & Error (\%) \\
\hline 10 & 770,5 & 7 & 3 \\
\hline 20 & 1541 & 19 & 5 \\
\hline 30 & 2311,5 & 28 & 6,6 \\
\hline 40 & 3082 & 41 & 2,5 \\
\hline 50 & 3852,5 & 49 & 2 \\
\hline 60 & 4623 & 62 & 3,3 \\
\hline 70 & 5393,5 & 71 & 1,4 \\
\hline 80 & 6164 & 80 & 0 \\
\hline 100 & 6934,5 & 91 & 1,1 \\
\hline
\end{tabular}

\section{Pengujian tingkat keakurasian pembacaan sisa pakan}

Pengujian trakhir adalah melihat kinerja alat selama 10 hari, dalam 10 hari pengujian alat mampu bekerja sesuai jadwal pemberian yaitu pukul 07.00 dan 17.00. Tabel 4 menunjukkan hasil pengujian tersebut.

Tabel 4. Hasil Pengujian Kinerja Alat

\begin{tabular}{cccc}
\hline Tanggal & Pukul 07.00 & Pukul 17.00 & Indikator Keberhasilan Pakan Terlontar \\
\hline 3 Januari 2021 & Berhasil melontar & Berhasil melontar & Berhasil Terbaca \\
\hline 4 Januari 2021 & Berhasil melontar & Berhasil melontar & Berhasil Terbaca \\
\hline 5 Januari 2021 & Berhasil melontar & Berhasil melontar & Berhasil Terbaca \\
\hline 6 Januari 2021 & Berhasil melontar & Berhasil melontar & Berhasil Terbaca \\
\hline 7 Januari 2021 & Berhasil melontar & Berhasil melontar & Berhasil Terbaca \\
\hline 8 Januari 2021 & Berhasil melontar & Berhasil melontar & Berhasil Terbaca \\
\hline
\end{tabular}


Procedia of Engineering and Life Science Vol. 1. No. 2 Juni 2021

Seminar Nasional \& Call Paper Fakultas Sains dan Teknologi (SENASAINS 2nd)

Universitas Muhammadiyah Sidoarjo

\begin{tabular}{ccll}
\hline 9 Januari 2021 & Berhasil melontar & Berhasil melontar & Berhasil Terbaca \\
\hline 10 Januari 2021 & Berhasil melontar & Berhasil melontar & Berhasil Terbaca \\
\hline 11 Januari 2021 & Berhasil melontar & Berhasil melontar & Berhasil Terbaca \\
\hline 12 Januari 2021 & Berhasil melontar & Berhasil melontar & Berhasil Terbaca \\
\hline
\end{tabular}

\section{KESIMPULAN}

Dari hasil penelitian dan analisa secara umum dapat simpulkan bahwa jika dilihat dari kinerja sensor proximity dan sensor jarak menggunakan infrared untuk mendeteksi keberhasilan pakan terlontar dan sisa pakan dalam wadah adalah sebagai berikut: Sensor proximity infrared berhasil mendeteksi lontaran pakan ikan secara waktu nyata sesuai dengan jadwal lontaran maupun mode pengoperasian manual, dan berhasil menampilkan informasi ke platform Blynk. Tingkat keberhasilan sensor mendeteksi keberhasilan lontaran adalah 100\%. Sensor jarak infrared membutuhkan proses kalibrasi untuk menyesuaikan bentuk dan ukuran wadah pakan, data yang diperoleh dari hasil kalibrasi berhasil ditampilkan di platform Blink. Rata-rata persentase kesalahan dari total pengujian adalah sebesar 5,1\%.

\section{REFERENSI}

[1] M. Hasanuddin dan A. Andani, "Alat Pemberi Pakan Ikan Otomatis Terjadwal dengan Sistem Kendal Mikrokontroler," IT Media Informasi IT STMIK Handayani, vol. 10, no. 1, pp. 31-36, 2019.

[2] D. Prijatna dan H. Handarto, "RANCANG BANGUN PEMBERI PAKAN IKAN OTOMATIS," Teknotan vol. 12, no. 1, pp. 30-35, 2018.

[3] A. M. Putra dan A. B. Pulungan, "Alat Pemberi Pakan Ikan Otomatis," JTEV (JURNAL TEKNIK ELEKTRC DANVOKASIONAL), vol. 6, no. 2, pp. 113-121, 2020.

[4] S. Wahyuni, M. Mudarris, A. Askar, S. R. Ayusnin dan S. G. Zain, "PAPAKINOTO (PENEBAR PAKAN IKAN OTOMATIS) 'UPAYA PENINGKATAN PRODUKSI DAN EFIISIENSI WAKTU BUDIDAYA TAMBAK IKAN TAWAR MASYARAKAT BELAWA KABUPATEN SOPPENG”," Pendidikan Teknolog Pertanian, vol. 4, no. -, pp. 42-49, 2018.

[5] A. Ardiwijoyo, J. Jamaluddin dan A. M. Mappalotteng, "RANCANG BANGUN ALAT PEMBERI PAKAN IKAN DENGAN SISTEM AUTOMATISASI BERBASIS ARDUINO UNO R3 DENGAN SISTEN KENDALI SMS,” Pendidikan Teknologi Pertanian, vol. 4, no. -, pp. 12-20, 2018.

[6] A. Rayes dan S. Salam, Internet of Things From Hype to Reality, -: Springer, 2019.

[7] W. Cahyadi, M. Sa'id dan A. R. Chaidir, "Optimasi Racing Line pada ECU (Electronic Control Unit) Mobi Listrik Berbasis Fuzzy Logic Control,” ELKOMIKA: Jurnal Teknik Energi Elektrik, Teknik Telekomunikasi, \& Teknik Elektronika, vol. 8, no. 2, pp. 454-466, 2020.

[8] S. Valluri, A. G. Sagar dan S. Shanmugam. G , "IOT Based Real Time Monitoring Mobile Robot,' International Journal for Research in Applied Science \& Engineering Technology (IJRASET), vol. 5, no. 5, pp 105-109, 2017.

[9] S. Janpla, N. Tachpetpaiboon dan C. Jewpanich, "Development of Automatic Home-Based Fish Farming Usin€ the Internet of Things," International Journal of Recent Technology and Engineering (IJRTE), vol. 8, no. 2 pp. 2297-2304, 2019.

[10] D. Sivamani, S. R. Dr. , R. J. Ganesh dan D. A. N. Ali, "Smart Incubator using Internet of Things," Internationa Journal for Modern Trends in Science and Technology, vol. 4, no. 9, pp. 23-27, 2018. 